Canadian

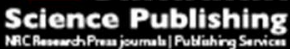

Canadian Geotechnical Journal Revue canadienne de géotechnique

\title{
Capillary Rise Experiment to Assess the Effectiveness of an Enzyme Soil Stabilizer
}

\begin{tabular}{|r|l|}
\hline Journal: & Canadian Geotechnical Journal \\
\hline Manuscript ID & cgj-2016-0511.R2 \\
\hline Manuscript Type: & Article \\
\hline Date Submitted by the Author: & 02-May-2017 \\
\hline Complete List of Authors: & $\begin{array}{l}\text { Chandler, Neil; Red River College, Civil Engineering Technology } \\
\text { Palson, John; Cypher Environmental Ltd } \\
\text { Burns, Todd; Cypher Environmental Ltd }\end{array}$ \\
\hline Keyword: & $\begin{array}{l}\text { Enzyme additive, capillary rise, water adsorption, subgrade stabilization, } \\
\text { laboratory testing }\end{array}$ \\
\hline \multicolumn{2}{|c}{} \\
\hline
\end{tabular}


Capillary Rise Experiment to Assess the Effectiveness of an Enzyme Soil Stabilizer

Neil Chandler (corresponding author)

Red River College, 2055 Notre Dame Ave, Winnipeg, Manitoba, R3H 0J9

nchandler@,rrc.ca

John Palson

Cypher Environmental Ltd, 1149 St. Matthews Ave, Winnipeg, Manitoba, R3G 0J8

Todd Burns

Cypher Environmental Ltd, 1149 St. Matthews Ave, Winnipeg, Manitoba, R3G 0J8 


\section{ABSTRACT}

2 An experimental program to assess of the attributes of an enzyme soil stabilizer is described.

3 The focus of the program were two one-year capillary rise experiments designed to test the

4 influence of the soil additive on the soil's adsorption of water. The enzyme additive is typically

5 applied to marginal clay-based soils to improve the performance of road subgrades. The study

6 investigated the potential increase in shear strength and the reduction in swelling. The two long-

7 term soil column tests were conducted to measure water absorption due to capillary rise with,

8 and without, enzyme treatment. The test results demonstrated that the addition of the enzyme

9 soil additive had the effect of reducing water retained in the pore spaces of a partially-saturated

10 soil. The soil treated with the enzyme additive absorbed a lower quantity of water in the

11 capillary rise test, and at a slower rate of absorption. The results from a concurrent suite of tests

12 suggested that partially-saturated clay having lower moisture content was linked to an increase in

13 shear strength.

14

15 Keywords

16 Enzyme additive, capillary rise, water adsorption, subgrade stabilization, laboratory testing 
1. Introduction

19 Red River valley soils are rich in clay and silt. While this may be beneficial for agricultural uses,

20 fine-grained soils can be problematic as construction materials for roads and foundations. Clay

21 soils, owing to their molecular structure, have an affinity for water making them weaker during

22 wet weather. Clay often experiences considerable swelling and shrinkage in response to moisture

23 changes, and if silt is present, can be prone to frost heaving in the winter. A number of solutions

24 are available to mitigate potential construction problems, ranging from replacing the fine-grained

25 soil with granular material and/or the use of geosynthetic reinforcement to the use of soil

26 additives. Demonstrating an economically viable improvement of marginal subgrade soils, by

27 application of soil improvement additives, would have a benefit for roadway construction.

29 An emerging category of soil additives are the natural organic, bio-degradable multi-enzyme

30 products. Enzymes are natural organic compounds, which act as catalysts. Enzyme products can

31 also include biodegradable surfactants to reduce the surface tension and promote enzymatic

32 reactions. Marasteanu et al. (2005) report that enzymes have been applied with success to road

33 and highway projects in over forty counties since the 1970s. Although this type of additive has

34 been applied to stabilizing soils for decades (Khan and Sarker 1993) there is still very little

35 information in the technical literature describing its use in road construction.

37 Different theories have been espoused in the literature as to how enzymes improve soil

38 performance. These theories are documented in Section 8 of this paper with reference to the

39 results of the current research. To summarise, enzymes are believed to combine with large

40 organic molecules that are adsorbed to the clay surfaces, they act as catalysts for cation 
41 exchange, they may improve chemical bonding, and/or they include proteins that act as

42 surfactants reducing the surface tension in the water surrounding the clay particles. Enzyme

43 products have no negative environmental affects, as might be the case with lime, cement,

44 bitumen, chlorides, synthetic polymers, or acid-based additives. Anecdotal evidence from

45 applications around the world suggests that adding the enzyme stabilizer to predominantly clay-

46 based road sub-grade material enhances the material's bearing capacity. This affect is most

47 apparent when the soil is less than saturated.

49 The primary incentive for using enzyme additives would for be its positive environmental

50 attributes. Also, since only $1 \mathrm{~L}$ of enzyme treatment is added to about $30 \mathrm{~m}^{3}$ of compacted soil,

51 enzyme treatment is less expensive when compared with cement additives or other hydraulic

52 binders. In addition, enzyme treated clay remains flexible and elastic, whereas cemented soils

53 are rigid and once they crack are not fixable. Enzyme treated clay soils retain their self-healing

54 qualities. A disadvantage for enzyme stabilization is that, to be effective, the soil must be at or

55 below its optimum moisture content when treated. The enzyme treated soil must then be allowed

56 to adequately dry to obtain best results. The paucity of documented case studies or laboratory

57 testing results, relative to the information available for hydraulic binders, can also be seen as a

58 disadvantage when considering enzymes for use in road improvement projects. In particular,

59 there is little discussion in the literature on the effectiveness of enzyme treatment in response to

60 drying and wetting cycles.

61

62 2. Review of previous laboratory studies 
64 A few laboratory studies into the effectiveness of enzyme additives to improve soil properties

65 have been performed. However, the experimental findings have been inconsistent. Tingle and

66 Santoni (2003) tested four enzyme products with two products producing a 30\% gain in

67 unconfined compressive strength of high-plastic clay, while the other two products produced no

68 strength gain at all. A low plastic material with less than $27 \%$ clay-size particles had almost no

69 strength gain when treated with any product. Rauch et al. (2002) also provided varied results and

70 concluded that the as-prepared moisture content had as great effect on the strength data as the

71 application of the enzymes. Velasquez et al. (2006) concluded that one of the two enzyme

72 additives tested greatly increased the elastic resilient modulus of a high plastic clay making it

73 much stiffer under dynamic loading. Mgangira (2009), Venkatasubramanian and Dhinakaran.

74 (2011), Eujine et al. (2014) and Agarwal and Kaur (2014) all observed an increase in strength

75 with curing time for most of the enzyme products tested, while Parsons and Milburn (2003)

76 found no significant increase in soil strength with enzyme treatment. Common themes in most

77 publication were that the enzyme additive worked better on higher plasticity soils with greater

78 clay content, that the product reduced the soils affinity for water, and that not all enzyme

79 products produce positive results in the laboratory. Inconsistency of results from one researcher

80 to the next may be due, in part, to differences in specimen preparation and curing methodology.

82 The study described in this paper was performed at the Robert Kwok Memorial Lab at Red River

83 College in Winnipeg, Manitoba. The purpose of the study was to compare properties of a local

84 soil treated with an enzyme additive to those of the same untreated soil. The experimental

85 protocol was developed to test the hypothesis that the enzyme additive affects a clay soil's ability

86 to absorb water or release it to evaporation. The central components of the experimental

87 program were two year-long capillary rise tests to assess water adsorption with and without the 
88 enzyme additive. Tests were also concurrently carried out to compare strength and swelling.

89 The contents of this paper will summarise the results from strength and swelling tests, with the

90 capillary absorption tests described in greater detail.

91

92 3. Soil characteristics and specimen preparation

93

94 The soil was chosen at random from the Winnipeg region. The intent was to obtain sufficient

95 soil with consistent properties from the lacustrine sediments of the Red River flood plain in the

96 Lake Agassiz Basin. Although regional fine-grained soils are similar in appearance throughout

97 Southern Manitoba, soil plasticity, fine particle size distribution, and compaction characteristics

98 can vary significantly from location to location. About $100 \mathrm{~kg}$ of clay soil was collected from

99 one site to be used for all the soil tests. Only one enzyme product (Earthzyme) was used in the

100 study $^{1}$.

101

102 EarthZyme is a product that is added to clay-based soils. Its use is intended to increase soil

103 compaction and consequently bearing capacity for roadway construction. EarthZyme consists of

104 three primary elements: (1) an ionic solution that interacts with clay minerals and reduces the

105 thickness of the water layer bound to the clay particles, (2) a surfactant to reduce the water

106 viscosity, and (3) a combination of enzymes that facilitate ion exchange between clay particles

107 and the ionic solution.

108

109 The soil had a liquid limit of 85 , a plastic limit of 37 and a plasticity index of 47 . On the

110 plasticity chart, the soil characteristics plot just above the A-Line (the boundary between $\mathrm{MH}$

\footnotetext{
${ }^{1}$ Earthzyme is a product of Cypher Environmental Ltd.(1149 St. Matthews Ave, Winnipeg, Manitoba), and was used exclusively in this study.
} 
111 and $\mathrm{CH}$ ) and so would be classified as a high plastic clay $(\mathrm{CH})$. The grain size analysis indicated

112 that the soil contained $73 \%$ clay-sized particles $(<0.002 \mathrm{~mm}), 24 \%$ silt-sized particles and $3 \%$

113 sand (retained on the No. 200 sieve). The soil's specific gravity was measured to be 2.72 . The

114 soil could be compacted to a dry density of approximately $1450 \mathrm{~kg} / \mathrm{m}^{3}$ at moisture contents

115 between 15 and 20\%. The clays of the Red River basin typically swell significantly when

116 inundated with water. This soil was no different, experiencing $11 \%$ volume increase in free

117 swell tests for specimens prepared at densities near the MDD.

119 A combined total of 43 specimens were prepared for unconfined compression, unconsolidated120 undrained, consolidated-undrained, swelling pressure and tempe cell tests. All specimens were 121 pre-mixed to an average moisture content of $28 \%$ (with a $2.5 \%$ standard deviation) by weight

122 with an average dry density of $1510 \mathrm{~kg} / \mathrm{m}^{3}$ (with a $57 \mathrm{~kg} / \mathrm{m}^{3}$ standard deviation). To prepare the 123 treated soil, $0.6 \mathrm{~mL}$ of Earthzyme was added to $4 \mathrm{~kg}$ of water before mixing with $25 \mathrm{~kg}$ of dry

124 soil (1 L treatment for $30 \mathrm{~m}^{3}$ of compacted soil). Remolded specimens for strength and swelling

125 tests were compacted in layers inside a steel mold using a Proctor hammer, employing the same 126 compaction energy as in a Proctor test. The strength and swelling pressure soil specimens were 127 trimmed to size, wrapped in newsprint, and allowed to dry for usually seven days. The drying 128 stage was incorporated to allow the soil-enzyme mixture to cure under conditions representative 129 of those in the field. The purpose of the newsprint was to slow the rate of drying in order to 130 prevent splitting due to shrinkage. The ambient relative humidity in the laboratory was an 131 average of $32 \%$ and the residual moisture content of the fully-dried soil was $9 \%$ on average (with 132 a standard deviation of $3.3 \%$ ). Specimens air-dried in the lab would achieve the residual 133 moisture after about one week following preparation, although some variability in the final 134 moisture content was recorded. Owing to shrinkage during drying, the dry density of the air- 
135 dried soil increased, on average, to $1870 \mathrm{~kg} / \mathrm{m}^{3}$ (with a standard deviation of $48 \mathrm{~kg} / \mathrm{m}^{3}$ ). The

136 treated and untreated specimens were both prepared at the same time, using the same specimen

137 preparation methods and cured in the same temperature and humidity environment. The

138 exception being the soil column capillary absorption tests, which had to be performed

139 sequentially owing to material and equipment limitations.

140

141 4. Strength and swelling

143 Unconfined compression tests and California Bearing Ratio (CBR) tests were conducted

144 following ASTM procedures. Drying and curing for one week tended to produce very strong

145 unconfined compression specimens. The seven day duration of the drying stage was

146 subsequently reduced to allow the specimens to be tested at higher moisture contents. Fig. 1

147 illustrates a typical unconfined compression tests result. The enzyme treated soil was usually

148 dryer and slightly denser than the untreated specimen. As a consequence, the treated soil was

149 usually stronger than untreated soil and an average of $60 \%$ stiffer as evidenced by a steeper slope

150 on the stress-strain diagram. The observation that treatment with enzymes produced a stiffer soil

151 is in keeping with the findings of Velasquez et al. (2006) that enzyme treatment produced a soil

152 with a higher resilient modulus. The compilation of data in Fig. 2 suggests that soil strength was

153 more dependent more upon moisture content than on soil treatment with the enzyme additive. It

154 is important to note that even the wettest specimen in Fig. 2 (a volumetric moisture of $32 \%$ or

155 gravitational moisture of $18 \%$ ) had experience considerable drying shrinkage during the curing

156 period. As a consequence, all the unsaturated dried/cured specimens would be expected to be

157 much stronger than remolded specimens tested without drying, with or without treatment.

158 Vanapalli et al. (1996) document the theoretical relationship between increasing soil strength, 
159 decreasing moisture content and increasing soil-water suction, supporting the concept that

160 strength increases for dryer soils. In the current study, the treatment of the soil with the enzyme

161 additive produced a dryer and consequently stronger material, provided it was cured for the same

162 duration as the untreated specimen. Fig. 3 illustrates the increase in soil dry density as a function

163 of curing time. The presumption is that decreased moisture leads to shrinkage and density

164 increase with a consequent increase in strength.

166 The California Bearing Ratio (CBR) test uses a volume of soil more than twelve times larger

167 than the unconfined compression specimen, with less overall drying occurring during the one

168 week of curing. The CBR test is the standard test method for determination of the strength of

169 sub-grade material for use in road construction. CBR test data for treated and non-treated soils

170 are provided in Fig. 4. ASTM D1833 (2014) requires the CBR value at $5.0 \mathrm{~mm}$ of penetration to

171 be used if the value at $5 \mathrm{~mm}$ is consistently greater than the value at $2.5 \mathrm{~mm}$. The treated CBR

172 value of 28 compared with the untreated CBR of 21 suggests a $38 \%$ increase in bearing strength

173 when the soil is treated with the enzyme additive.

175 Consolidated-undrained triaxial compression tests were also performed on saturated treated and

176 untreated soil specimens at confining pressures up to $280 \mathrm{kPa}$ with $140 \mathrm{kPa}$ internal pore

177 pressure (back pressure) at the start of each test. The effective cohesion and effective angle of

178 internal friction were determined for both treated and untreated soil. The effective cohesion was

179 determined to be zero for both, while the effective angle of internal friction was approximately

$18034^{\circ}$ for both treated and untreated soil. There was no apparent improvement to effective strength

181 properties of this soil when the soil was saturated. Published research results are inconsistent

182 with respect to strength gain while saturated. Some researchers measured no increase (Parsons 
183 and Milburn 2003) while others observed a strength increase if the enzyme additive was allowed

184 to cure in saturated soil for 28 days (Venkatasubramanian and Dhinakaran 2011). Results from

185 the current study, for the specific soil used, indicate that the strength gain occurs when the soil is

186 only partially-saturated. However, no soaked CBR tests were performed on the test material.

187 Soaked CBR tests on some other enzyme treated soils have shown modest strength gains.

189 The ASTM procedure for swelling pressure measurement (ASTM D4546) provides three

190 methods for determining swelling pressure using consolidation test equipment. The "loading

191 after wetting" method was used in this study. The soil specimen was cut to the size of the

192 consolidation ring before being allowed to dry (cure) for seven days. The slightly smaller cured

193 specimens were returned to the fixed-diameter molds before being inundated with water and

194 allowed to free swell. The initial dry density after curing, and prior to inundation, for both the

195 treated and untreated soils was $1880 \mathrm{~kg} / \mathrm{m}^{3}$, which due to curing-related shrinkage, was higher

196 than the as-prepared dry density. The moisture content at the end of the seven day curing period

197 varied between 5 and $8 \%$ by weight. The specimens were allowed to expand freely for several

198 days until swelling stopped. The vertical applied load was increased daily and the vertical

199 compression was measured. The compression data (in $\mathrm{mm}$ ) was converted to dry density. The

200 vertical applied pressure was considered to be the swelling pressure. The swelling pressure as a

201 function of dry density for the treated and untreated specimens is provided in Fig. 5. The test

202 results from three treated specimens and three untreated specimens indicate that both the free

203 swell expansion and the swelling pressure are reduced for treated soils when compared with

204 untreated soils. Given that volume expansion is related to the increase in the water content, the

205 tests indicated that the untreated soil took on more water than the treated soil when an unlimited 206 supply of water was available. 
208 5. Water absorption and summary of mechanical testing

210 The strength and swelling test results indicated that the addition of an enzyme additive produced 211 a material that lost water to evaporation more quickly during drying than untreated specimens.

212 For a given drying time the treated soil was slightly more dense, had a greater stiffness and a

213 higher bearing strength than the untreated soil. Inundation of the fully dried swelling pressure 214 specimens resulted in less absorbed water for the treated soil than for the treated soil. A lower 215 quantity of absorbed water manifested itself as lower swelling pressures for the treated soil. The 216 implication from the data was that addition of the enzyme soil additive resulted in a decrease in 217 the soil's affinity for water. The enzyme additive includes a surfactant. Therefore, it is possible 218 that the additive reduced the surface tension along air-water interfaces within the partially219 saturated pore spaces. The reduced surface tension resulted in lower pore-water suction and a 220 corresponding decrease in the water content. The relationship between the volumetric water 221 content and pore-water suction is referred to as the Soil-Water Characteristic Curve (SWCC).

222 Theory suggests that the addition of the enzyme shifted SWCC towards a lower volumetric water 223 content at any given value of suction. Measurement of the SWCC using Tempe cells and vapour 224 equilibrium was attempted for the soil used in the experiments. The inability to obtain usable 225 results from these tests was attributed to equipment limitations, such as the ceramic air entry 226 value, and considerable data scatter.

228 6. Soil column tests 
230 The purpose of the soil column tests was to compare the water adsorption of compacted clay

231 material with, and without, enzyme treatment. The soil was compacted in a $150 \mathrm{~mm}$ diameter

232 fixed wall plastic tube to a dry density of $1350 \mathrm{~kg} / \mathrm{m}^{3}$ at moisture contents between 15.5 and

$23317.5 \%$. The soil was compacted in place using a proctor hammer and the same lift thickness and

234 compaction energy as used in preparing the CBR tests, although the as-placed density in the

235 plastic tube was slightly less than the 1380 to $1450 \mathrm{~kg} / \mathrm{m}^{3}$ achieved in compaction molds. The

236 two soil columns were 1170 and $1100 \mathrm{~mm}$ in height. Five Decagon moisture sensors were

237 compacted inside the soil column. The lower $75 \mathrm{~mm}$ of the soil column was submerged in a

238 water bath and the soil column was allowed to absorb water through capillary action for

239 approximately one year. The upper surface of the column was open to the atmosphere. The

240 ambient air near the upper soil surface had a relatively constant temperature of $25^{\circ} \mathrm{C}$ and relative

241 humidity of $32 \%$. The test configuration diagram and photograph are provided in Fig. 6 ab.

243 Soil was compacted in $60 \mathrm{~mm}$ thick lifts using 56 blows per lift from a standard proctor

244 compaction hammer. In mixing the soil, $4 \mathrm{~kg}$ of water was added to $25 \mathrm{~kg}$ of dry soil. The

245 treated soil included $0.6 \mathrm{~mL}$ of the enzyme soil additive. The compacted soil column sat for one

246 week before water was added to the reservoir. Decagon moisture sensor data was recorded every

247 hour.

249 The Decagon moisture sensors measure the dielectric constant using capacitance/frequency

250 domain technology. The sensors were calibrated to the volumetric moisture content of the

251 compacted soil as used in the test. Prior to test assembly, the sensors were inserted into six

252 compacted soil specimens at volumetric water content between 15 and $40 \%$ (corresponding to 11

253 to $30 \%$ gravimetric moisture). Upon final disassembly of each test, the moisture and density 
254 were determined at each sensor location. The end-of-test data from the five sensor readings for

255 both tests provided an additional 10 data points for calibration. The relationship between

256 volumetric water content and sensor reading is provided Fig. 7.

258 The volumetric moisture content is the volume of water per unit total volume of soil, expressed 259 as a percent. The relationship between volume moisture $\left(w_{v o l}\right)$ and gravimetric moisture $(w)$ is as 260 follows:

$261[1] \quad w_{v o l}=w \frac{\rho_{d r y}}{\rho_{w}}$,

262 where $\rho_{d r y}$ is the dry density and $\rho_{w}$ is the density of water. The change in moisture content as

263 measured by the five moisture sensors from the treated test is provided in Fig. 8. The rate of

264 change of moisture content (gravimetric moisture), as measured by sensors at 26 and $50 \mathrm{~cm}$

265 above the water level, are provided in Fig. 9 for both treated and untreated tests.

267 The first conclusion drawn was that capillary rise takes a long time to achieve moisture

268 equilibrium. Both the treated and untreated tests were disassembled after approximately twelve

269 months of operation. The analysis of capillary rise in sandy silt by Lu and Likos (2004) showed

270 that up to two years may be required for a partially-saturated soil to come into capillary

271 equilibrium. It is possible that the one-year tests described here were not completely stabilized.

272 Nonetheless, the soil column treated with the enzyme soil additive absorbed water at a slower 273 rate than the untreated soil and absorbed less water after approximately one year of capillary rise.

275 The soil columns were dismantled at the conclusion of each test. The end-of-test soil density and 276 moisture contents were determined at the location of each original lift. The soil was visibly

277 much wetter on the lower end and was hard and dry nearer the upper surface, as indicated in the 
278 photographs in Fig. 10. The individual compaction lifts were not discernible in the lower and

279 wetter portion of each test (Fig. 10a). Color change indicated an apparent water line at about

280 one-third of the way up the soil columns or approximately $30 \mathrm{~cm}$ above the waterline. The soil

281 easily broke apart along lift lines in the upper half of both treated and untreated columns

282 (Fig. 10b).

283

284 Pre- and post-test density determinations allowed a comparison between the initial and final

285 densities for both tests. The initial density was calculated by using the before and after lift

286 elevations that were measured after a known mass of soil had been compacted in place. The

287 post-test density measurements are likely more accurate than the pre-test measurements since 1

288 to $2 \mathrm{~mm}$ of uncertainty in as-placed lift elevation measurement represents about $50 \mathrm{~kg} / \mathrm{m}^{3}$ in

289 calculated density. The pre-test measurements were averaged over two lifts to provide less

290 scatter. A decreasing density during wetting would indicate swelling and an increasing density

291 during drying would indicate shrinkage. The dry density results from the treated test are shown

292 in Fig. 11, with both the treated and untreated tests providing similar data. The comparison

293 suggests that no swelling occurred in the lower portion of the test where the soil was getting

294 wetter, but shrinkage occurred near the top to the test where the soil dried out.

295

296 Gravimetric moisture content of each lift was determined by oven drying. The density of each

297 lift was used to calculate the volumetric water content (Equation 1). The density of the wetter

298 soil was determined by pushing a $63 \mathrm{~mm}$ diameter steel ring into the exposed base of each lift.

299 Determining the mass of the soil in the ring divided by the known volume provided the bulk

300 density. The dryer soil broke apart when attempts were made to push the ring into it. The

301 density of the dry soil was obtained by the wax density method. Gravimetric moisture content 
302 and measured dry density was converted to volumetric water content. The end-of-test volume

303 water content was plotted as a function of distance above the water line for both the treated and

304 untreated tests in Fig. 12. The volume moisture content indicated that the soil closer to the

305 waterline eventually became saturated, regardless of whether or not the soil was treated with the

306 enzyme product. The saturation volumetric water content at the as-placed density was $50 \%$.

308 Inspection of the moisture sensors during dismantling indicated that the sensors were in close

309 contact with the soil and the soil was uniformly compacted around the sensors during

310 installation. These observations suggested that the moisture content indicated by the sensors was

311 representative of the moisture content of the soil at that depth in the test. The end-of-test

312 moisture sensor readings are also provided in Fig. 12.

314 The vertical line on Fig. 12 at a volume moisture content of $22 \%$ represents the approximate as-

315 placed volumetric moisture. Soil to the right of this line had become wetter through adsorption

316 of water from below due to capillary rise. Soil to the left of the line had lost moisture though the

317 upper surface due to evaporation into the relatively dry (32\% relative humidity) ambient air.

318 Water was drawn up to a height of about $800 \mathrm{~mm}$ above the water line for the untreated soil,

319 while only up to a height of $500 \mathrm{~mm}$ for the treated soil. Soil with moisture content greater than

$32045 \%$ indicated a degree of saturation that was over $90 \%$, and both the treated and untreated soil

321 columns approached saturation water contents at heights just above the waterline.

323 The treated soil column was slightly shorter than the untreated column owing to material

324 shortage during preparation of the second test. The soil near the exposed surface was very dry

325 for both tests and had a degree of saturation of $17 \%\left(\mathrm{w}_{\mathrm{vol}}\right.$ of about $\left.8.5 \%\right)$ regardless of whether or 
326 not the soil was treated. The treated soil throughout the central region of the test had a volume

327 moisture content that was about 5\% lower throughout than the untreated soil. The five percent

328 decrease in moisture content represents $50 \mathrm{~kg}$ less water for every cubic metre of soil. Density

329 determination inaccuracy is speculated to be the reason for the anomaly at $600 \mathrm{~mm}$ above the

330 water line in the untreated data.

3327. Interpretation of results

334 The data throughout this study consistently suggests that, for the soil type tested, the addition of

335 the enzyme additive resulted in lower amount of water absorbed by the clay particles. The soil

336 column test demonstrated that both the total quantity of water absorbed and the rate of water

337 absorption are reduced by the enzyme additive. The addition of the enzyme did not affect the

338 strength of the saturated soil, nor did it reduce the residual moisture content of the fully-dried

339 soil. The addition of the enzyme reduced the absorption of moisture for soil that was less than

340 saturated, but not quite fully dried-out.

342 The addition of the enzyme to compacted soil had the effect of achieving a lower water content

343 compared with untreated soil specimens after a similar drying time. The consequence of greater

344 shrinkage associated with increased water loss produced a higher density material. The dryer

345 and denser treated soil had a higher bearing strength compared to untreated soil dried under the

346 same environmental conditions. Upon rewetting, the treated soil took in less water and incurred

347 a lower swelling volume change and generated lower swelling pressure than the untreated soil. 
349 Evidence from California Bearing Ratio tests indicated that treated soil had greater bearing

350 strength than untreated soil when it was allowed to dry or "cure" for seven days. The unconfined

351 compression test data indicated that the moisture content of the soil correlated well with strength.

352 The soil column tests suggested that treated soils above the water table would have about $5 \%$ less

353 water than untreated soils. The relationship between water content and unconfined strength

354 (Fig. 2) indicated that 5\% volumetric water content decrease would result in $2000 \mathrm{kPa}$ strength

355 increase, which is significant if the unsaturated soil has an unconfined strength of about 5000

$356 \mathrm{kPa}$. (Recall that these large strength values are for soil that has experience considerable drying

357 shrinkage). The strength gain for the treated soil in the unconfined compression or CBR tests

358 would occur for soil that was less than saturated, but not fully dried-out.

360 The capillary rise soil column tests confirmed that the treated soil took on less water and that

361 wetting due to capillary rise occurred at a slower rate. The transient moisture content change

362 was monitored over two consecutive one-year testing period using Decagon moisture sensors,

363 which were calibrated to the volumetric water content of the soil. The long time required to

364 achieve capillary rise equilibrium was unexpected when the test was assembled. The slow rate

365 of water movement was probably related to the low saturated hydraulic conductivity of the

366 compacted clay material $\left(8 \times 10^{-11} \mathrm{~m} / \mathrm{s}\right)$.

368 Although the soil column tests provided the most compelling evidence that the addition of an 369 enzyme additive reduced the rate and quantity of water absorption of a compacted clay soil, the

370 test took too long to run to be practical for future tests. The soil column test is very similar to 371 ASTM C-1585 (2013) a procedure used to determine the water "sorptivity" of concrete. The 372 mass of absorbed water in a $400 \mathrm{~cm}^{3}$ cylindrical concrete disc is recorded manually over three 
373 days. A similar method could be used for compacted clay. Another possibility for testing the

374 capillary adsorption of water by treated soil would be a hanging column test, similar to the one

375 outlined in ASTM D6836 (2002).

376

377 8. Enzyme stabilization process

379 Rauch et al. (2002) identified various obstacles preventing enzyme-based additives from

380 becoming more widely used. Included among these obstacles were the lack of standard methods

381 for either field application or laboratory testing of the product's effectiveness and that lab

382 evidence is often inconclusive or contradictory. Understanding the reason for the soil strength

383 improvement would benefit the development of laboratory test protocol. However, there are

384 conflicting theories put forward in the literature regarding the stabilization mechanism. The

385 predominant theory is that enzymes combine with large organic molecules that surround clay

386 particles and these positively charged molecules are adsorbed to the clay surface. The molecules

387 displace water within the diffuse double layer and neutralise the net charge on the clay surface

388 reducing the affinity of the clay for absorbed water (Rauch at al. 2002; Tingle et al. 2007). A

389 second theory is that the enzymes catalyze the reactions between clay and organic cations, which

390 in turn accelerates cation exchange without becoming part of the end product

391 (Venkatasubramanian and Dhinakaran 2011; Agarwal and Kaur 2014). A third theory suggests

392 that the enzymes improve chemical bonding and pull the soil particles closer together (Taha et al.

393 2013; Rajoria and Kaur 2014). Many researchers acknowledge that enzyme products are

394 surfactants and reduce the surface tension in pore water. Velasqueza et al. (2006) measured the

395 reduction in surface tension and postulated that it was a contributing factor for strength gain. 
396 Some of these proposed mechanisms are inter-related and most have a reduced affinity for

397 adsorbed water as a consequence.

399 A useful explanation of the diffuse double layer of water is provided by Kirkham and Powers 400 (1972). The diffuse double layer of water surrounding negatively charged clay particles includes 401 the Stern layer, a layer of water with immobile cations adsorbed to the surface of the clay, and 402 the diffuse layer having a high concentration of mobile cations. There is an electro-chemical 403 potential that draws the cations to the charged clay surface, but which decreases with distance 404 from the clay particles. This attractive force is affected by the concentration of solutes, the type 405 of solutes in solution, the type of cations adsorbed on the clay surface and the molecular 406 structure of the clay. The thickness of the diffuse layer of water will depend on how quickly the 407 electro-chemical attraction diminishes with distance away from the clay surface. Two of the 408 prevailing theories (i) enzymes coat the soil particles displacing cations in the diffuse layer, and 409 (ii) enzymes catalyse a reaction that results in the exchange of cations on the surface or Stern 410 layer, are two different mechanisms that have a similar result. Both reduce the net negative 411 charge and consequently reduce the thickness of the diffuse double layer. A third possible 412 mechanism is that the enzyme product reduces the surface tension in the pore water of partially413 saturated clay. The reduction in surface tension will result in decreased pore water suction and a 414 decreased thickness of the adsorbed water layer. All three mechanisms suggest a reduced 415 affinity for water in partially-saturated clay with the addition of enzymes. Some unsaturated soil 416 researchers have lumped the soil-water forces due to hydrostatic suction, osmotic potential and 417 adhesion potential into one term, referred to by Kirkham and Powers as either capillary potential 418 or matric potential. Irrespective of whether any one of the above theories works independently, 419 or if they all contribute concurrently, the net effect of adding enzymes to the soil pore water is 
420 the reduction of the matric potential and consequently a reduction in the thickness of adsorbed

421 water surrounding the clay surfaces.

423 The suggestion that the addition of an enzyme soil stabiliser decreases a clay soil's affinity for 424 water is supported by the results from the capillary rise tests described in this paper. In essence,

425 the enzymes result in a decrease in the moisture content of the soil at a given pore water suction,

426 if the soil is only partially saturated thus altering the soil water characteristic curve (SWCC).

427 Vanapalli et al. (1996) developed a model for the increase in shear strength with decrease in

428 moisture content and the corresponding increase in suction. The increase in strength occurs

429 within the transition phase of soil drying (or wetting) in which the soil is less than saturated but

430 above the residual moisture content. The suggestion in the current study is that enzyme

431 treatment lowers the clay soil's affinity for water so that the treated soil dries more quickly than

432 an untreated soil or dries to a lower moisture content at a given humidity and temperature

433 environment. Soil at a lower moisture content will have greater shear strength as indicated by

$434 \quad$ Fig. 2.

436 It is apparent from the literature that not all enzyme soil stabilizers have the same effectiveness

437 and that measured shear strength will be dependent upon the soil type and its characteristics.

438 There is a need to be able to demonstrate the strength increase for given soil type and enzyme

439 product. A problem with laboratory tests described in the literature is that there is not a

440 consistent approach to specimen preparation and curing. The curing process, more so than

441 specimen preparation, differs among researchers, with some specimens cured in wet curing

442 rooms, others sealed to prevent moisture loss during curing, and one researcher curing specimens

443 at constant relative humidity (Rauch et al 2002). Since benefit is gained as the soil dries but 
444 before it dries to its residual moisture, specimens should be allowed to dry during curing but

445 should not dry out completely. Specimens should not be sealed, nor cured in 100\% humidity

446 curing rooms. Humidity in sealed containers can be controlled using aqueous salt solutions.

447 CBR and unconfined compression test specimens should both be cured in a controlled humidity 448 environment to facilitate comparisons of the findings.

9. Summary

452 The paper describes the assessment of the attributes of an enzyme additive as applied to 453 improving the performance of marginal clay-based soils for road subgrades. The study 454 investigated the potential improvement to strength and the effect on swelling. Two long-term 455 soil column tests were conducted to measure water absorption during capillary rise with, and 456 without, enzyme treatment. The test results demonstrated that the addition of the enzyme soil 457 additive had the effect of reducing water retained in the pore spaces of a partially-saturated soil.

458 The soil treated with the enzyme additive absorbed a lower quantity of water in the capillary rise 459 test, and at a slower rate of absorption.

461 The strength tests demonstrated that the water content of the partially-saturated soil strongly 462 influenced strength. The soil with enzyme additive had a greater bearing strength than the 463 untreated soil as determined using California Bearing Ratio (CBR) tests. Under similar drying 464 times and environmental conditions the treated soil attained lower moisture content and the 465 associated shrinkage produced a higher density material than the untreated soil. The premise is 466 that the enzyme additive allowed the soil to lose a greater amount of pore water to evaporation. 467 The treated soil, having a lower water content and higher dry density, consequently achieved a 
468 greater bearing strength. The attributes of the enzyme soil additive are most apparent under

469 partially-saturated soil conditions where the soil is neither fully-saturated nor completely dried to

470 its residual water content. The lower rate of reabsorption of water for the treated soil had a

471 related beneficial attribute of reducing swelling upon re-wetting.

472

473 Two one-metre high capillary rise soil column tests were each performed over a one year

474 duration. The tests indicated a very slow rate of capillary-induced water movement in partially-

475 saturated compacted clay for either treated or untreated soil. Results demonstrated that the soil

476 treated with the enzyme additive absorbed less water and absorbed water at a slower rate than the

477 untreated soil. The results from the soil column test were the strongest evidence to support the

478 premise that the enzyme additive reduces the soil's affinity for water.

480 Acknowledgements

481 The authors acknowledge the funds received to purchase the moisture sensors from Red River 482 College's CARD (College Applied Research Development) fund. The authors also acknowledge 483 the help received from Narong Piamsalee with equipment preparation and test disassembly and 484 Sean James with the conduct of many of the strength tests and with input into the design concept 485 of the soil column test. 


\section{References}

Agarwal, P., and Kaur, S. 2014. Effect of bio-enzyme stabilization on unconfined compressive strength of expansive soil. International Journal of Research in Engineering and Technology. 3(5): 30-33. Available at http://www.ijret.org.

ASTM Standard C1585. 2013. Standard test method for measurement of absorption of water by hydraulic-cement concretes. ASTM International, West Conshohocken PA.

ASTM Standard D1883. 2014. Standard test method for CBR (California Bearing Ratio) of laboratory-compacted soils. ASTM International, West Conshohocken PA.

ASTM Standard D4546. 2014. Standard test methods for one-dimensional swell or collapse of soils. ASTM International, West Conshohocken PA.

ASTM Standard D6836. 2002. Standard Method for determination of the soil water characteristic curve for desorption using a hanging column, pressure extractor, chilled mirror hygrometer, and /or centrifuge. ASTM International, West Conshohocken PA.

Eujine,G.N., Somervell, L.T., Chandrkaran, S., and Sankar, N. 2014. Enzyme stabilization of high liquid limit clay. Electronic Journal of Geotechnical Engineering. Vol 19(W). Available at http://www.ejge.com.

Khan, L.I., and Sarker, M. 1993. Enzyme enhanced stabilization of soil and fly ash. In: Fly Ash for Soil Improvement. ASCE GSP 36, New York. pp. 43-57.

Kirkham, D., and Powers, W.L. 1972. Advanced soil physics. Robert E. Krieger Publishing Company, Inc.: Malabar, Florida.

Lu, N., and Likos, W.J. 2004. Rate of capillary rise in soil. Journal of Geotechnical and Geoenvironmental Engineering 30(6):646-650. 
Marasteanu, M.O., Hozalski, R, Clyne, T.R., and Velasquez, R. 2005. Preliminary Laboratory Investigation of Enzyme Solutions as a Soil Stabilizer. Minnesota Department of Transportation (Research Services Section) Report MN/RC-2005-25.

Mgangira, M.B. 2009. Evaluation of the effects of enzyme-based liquid chemical stabilizers on subgrade soils. In: Proc. $28^{\text {th }}$ Southern African Transport Conference (SATC) July 6-9, 2009. Pretoria, South Africa.

Parsons, R., and Milburn, J. 2003. Engineering Behavior of Stabilized Soils. Journal of the Transportation Research Board - Transportation Research Record, 1837: 20-29.

Rajoria, V., and Kaur, S. 2014. A review on the stabilization of soil using bio-enzyme. International Journal of Research in Engineering and Technology, 3(1): 75-78. Available at http://www.ijret.org.

Rauch, A., Harmon, J., Katz, L., and Liljestrand, H. 2002. Measured effects of liquid soil stabilizers on engineering properties of clay. Journal of the Transportation Research Board - Transportation Research Record, 1787:33-41.

Taha, M.R., Kahn, T.A., Jawad, I.T., Faroozi, A.Akbar., and Faroozi, A.Asghar. 2013. Recent experimental studies in soil stabilization with bio-enzymes - a review. Electronic Journal of Geotechnical Engineering, Vol 18(R). Available at http://www.ejge.com.

Tingle, J., Newman, J., Larson, S., Weiss, C., and Rushing, J. 2007. Stabilization mechanisms of non-traditional additives. Journal of the Transportation Research Board - Transportation Research Record, 1989:59-67.

Tingle, J., and Santoni, R. 2003. Stabilization of clay soils with non-traditional additives. Journal of the Transportation Research Board - Transportation Research Record, 1819:72-83. 
Velasqueza, R.A., Marasteanua, M.O., and Hozalskia, R.M. 2006. Investigation of the effectiveness and mechanisms of enzyme products for subgrade stabilization. International Journal of Pavement Engineering, 7(3): 213-220.

Vanapalli, S.K., Fredlund, D.G., Pufahl, D.E., and Clifton, A.W. 1996. Model for the prediction of shear strength with respect to soil suction. Can. Geotech. J., 33(3): 379-392.

Venkatasubramanian, C., and Dhinakaran, G. 2011. Effect of bio-enzymatic soil stabilisation on unconfined compressive strength and California Bearing Ratio. Journal of Engineering and Applied Sciences, 6(5): 295-298. 
Figure Captions:

Figure 1. Unconfined compression test data for treated and untreated specimens.

Figure 2. Unconfined strength as a function of volumetric moisture content.

Figure 3. Density increase during drying.

Figure 4. Data from CBR tests on treated and untreated specimens.

Figure 5. Swelling pressure as a function of treated and untreated soil dry density.

Figure 6. (a) Experimental arrangement for soil column capillary rise test. (b) A photograph of soil column test (right).

Figure 7. Decagon moisture sensor calibration.

Figure 8. Moisture content versus time during capillary rise for the treated soil specimen.

Figure 9. Comparison of moisture content versus time for treated and untreated soil.

Figure 10. Photographs of the soil column at the end of the test. (a) Lower, wetter soil shown on the left and (b) higher, dryer soil shown on the right.

Figure 11. As-placed and end-of-test dry density for the treated soil test.

Figure 12. Comparison of end-of-test volumetric water content as a function of distance above the waterline. 


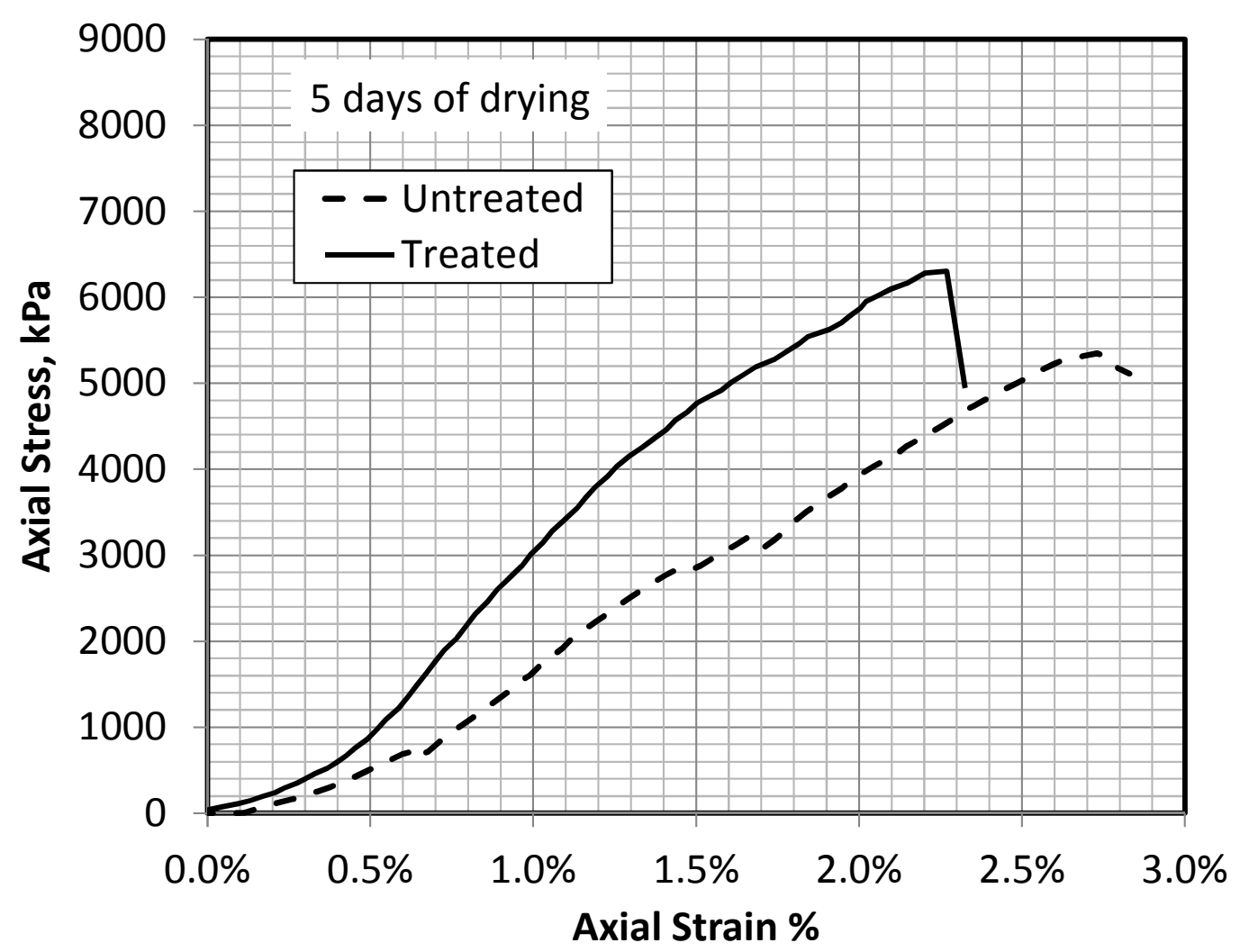

Figure 1. Unconfined compression test data for treated and untreated specimens. 


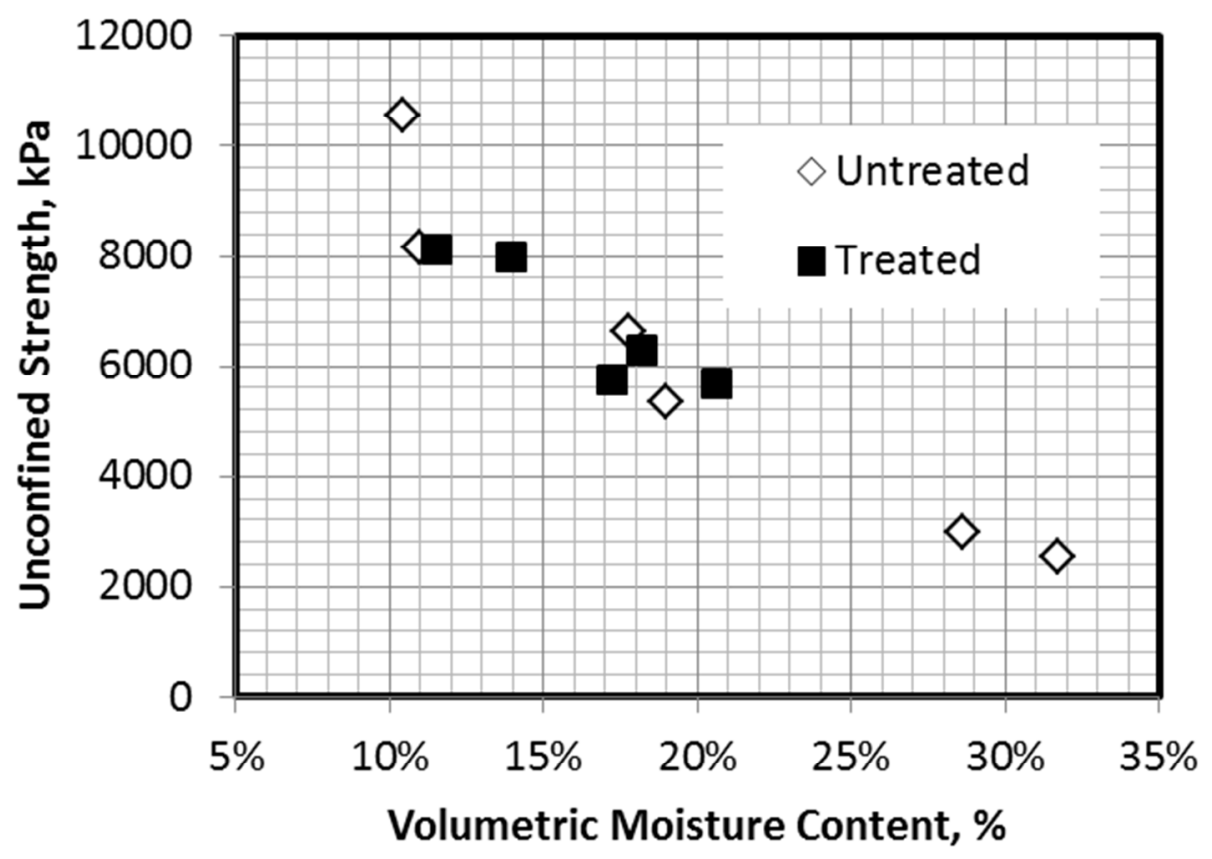

Figure 2. Unconfined strength as a function of volumetric moisture content. 


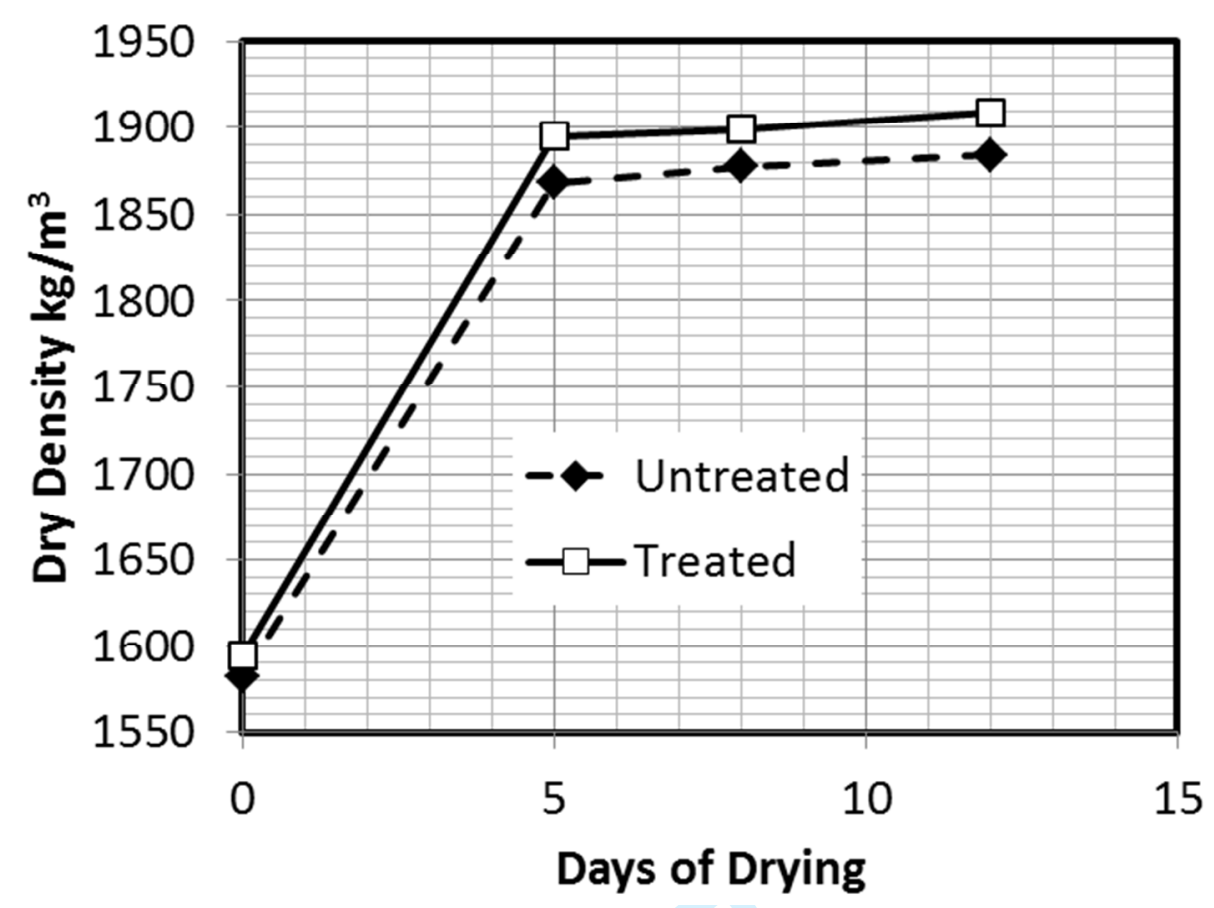

Figure 3. Density increase during drying. 


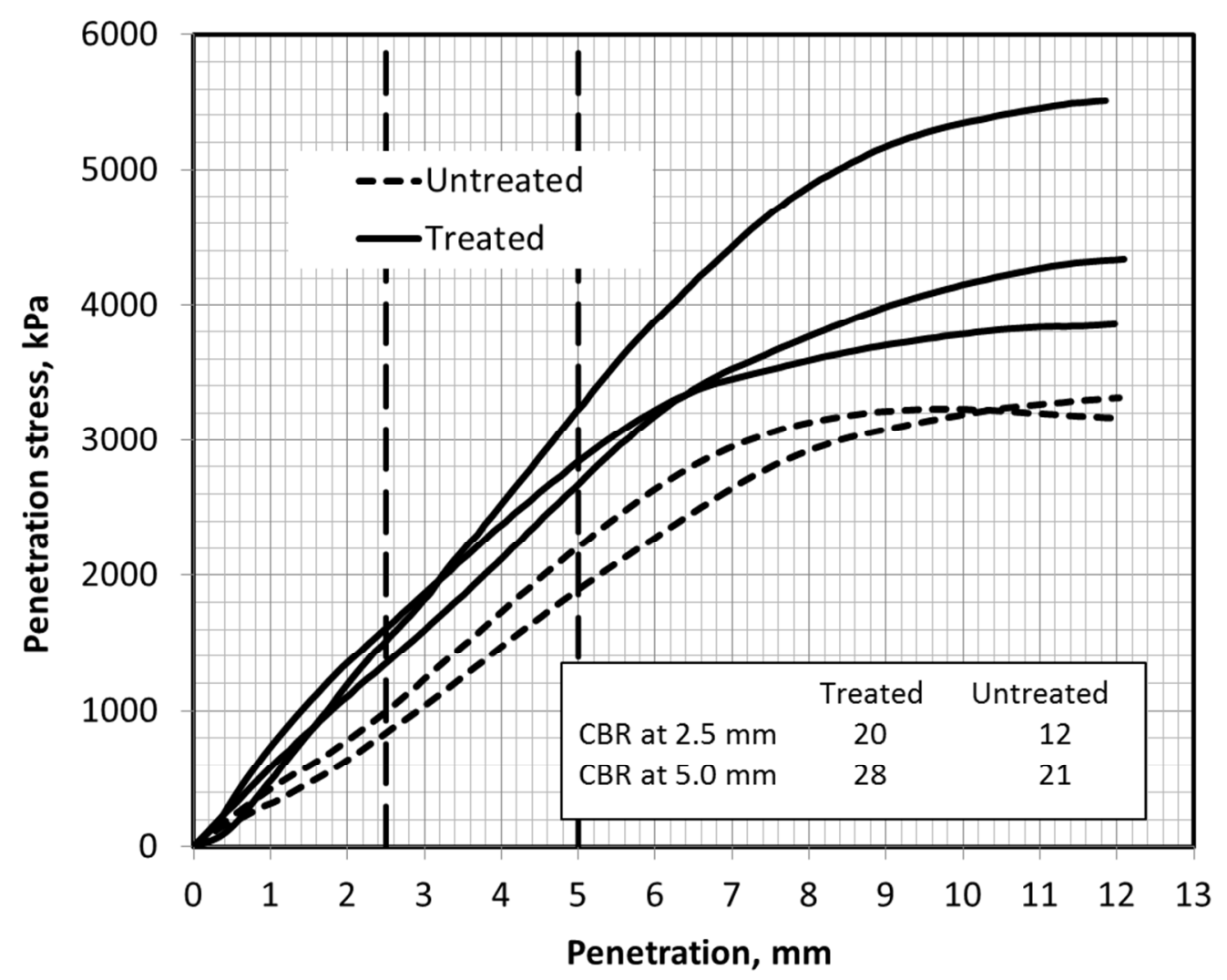

Figure 4. Data from CBR tests on treated and untreated specimens. 


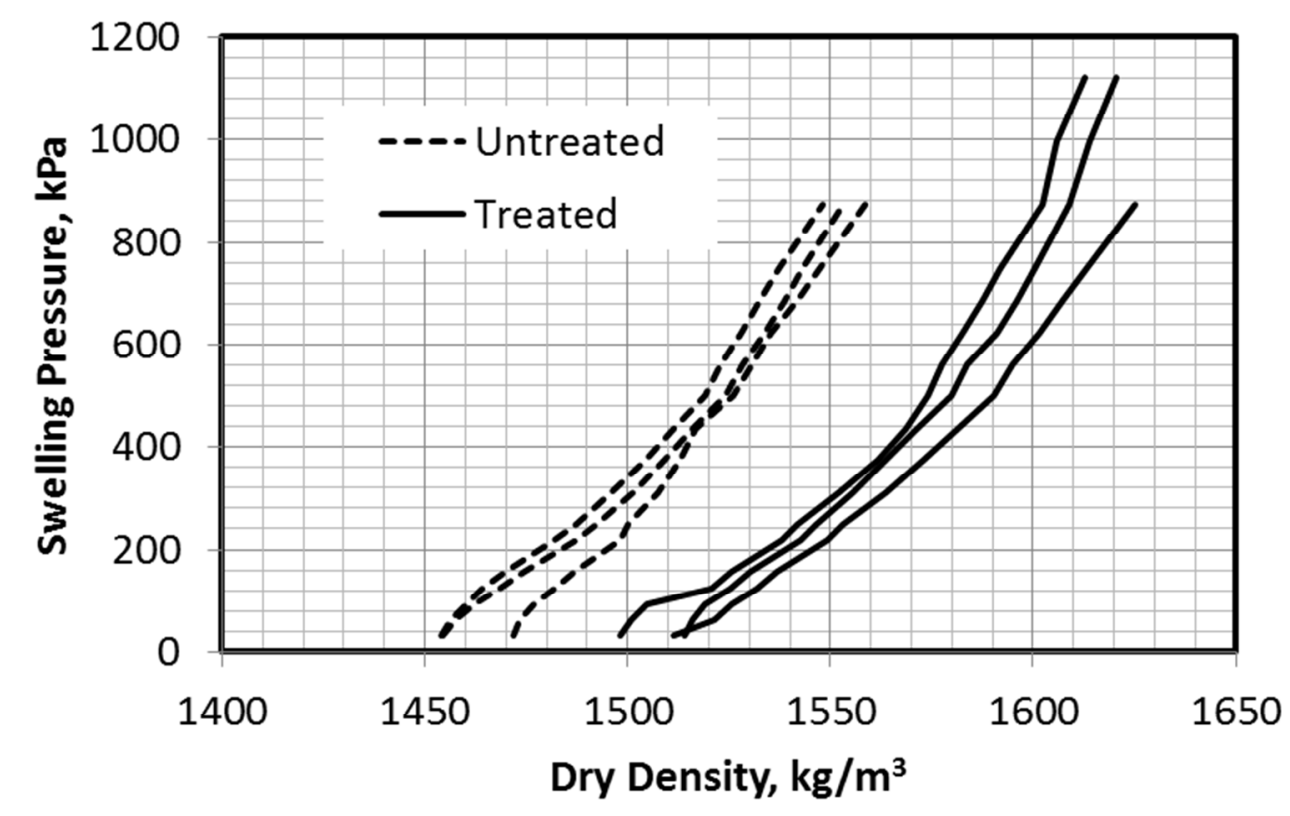

Figure 5. Swelling pressure as a function of treated and untreated soil dry density. 
(a)

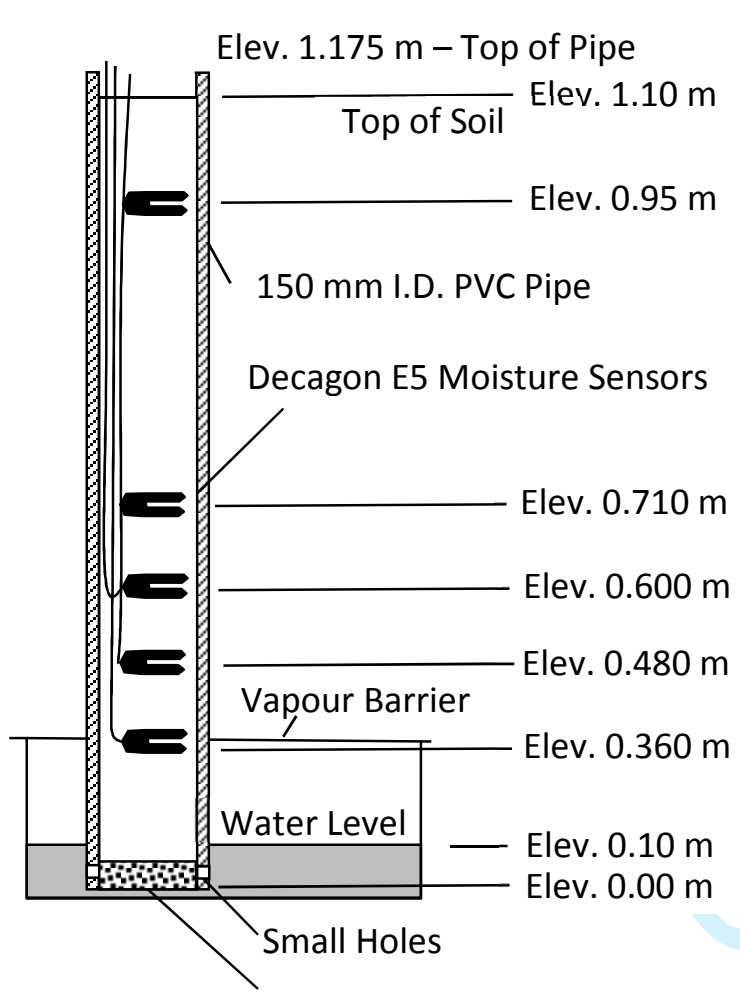

(b)

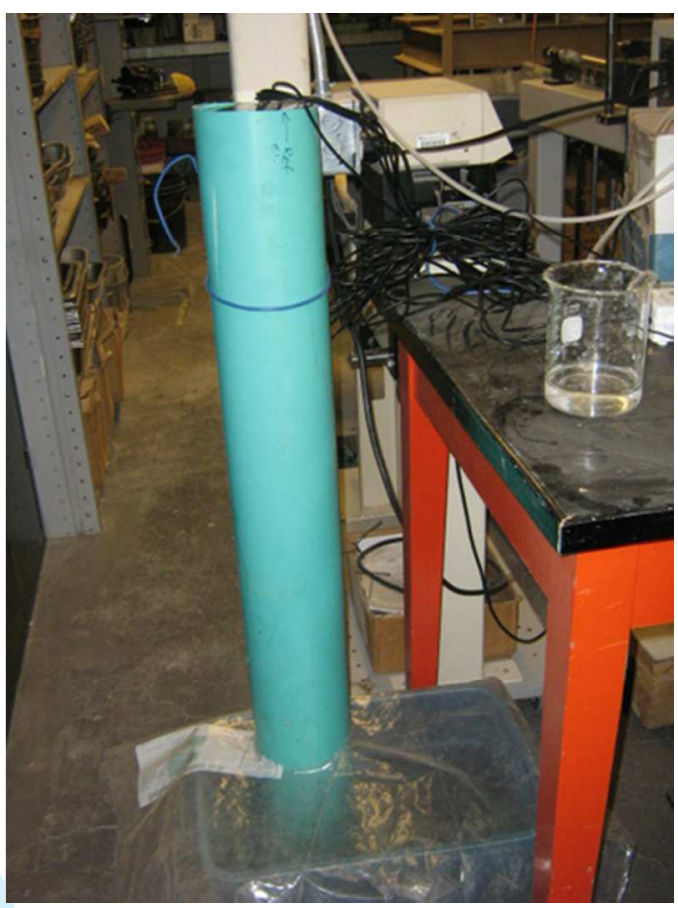

Figure 6. (a) Experimental arrangement for soil column capillary rise test. (b) A photograph of soil column test. 


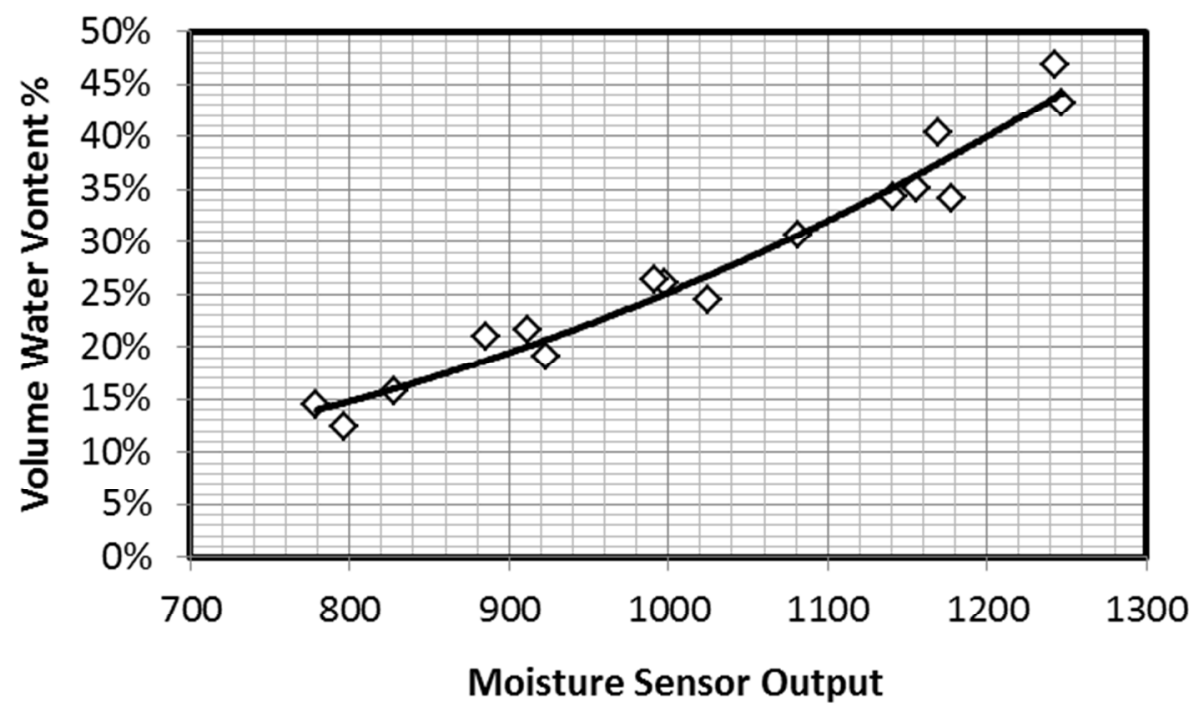

Figure 7. Decagon moisture sensor calibration. 


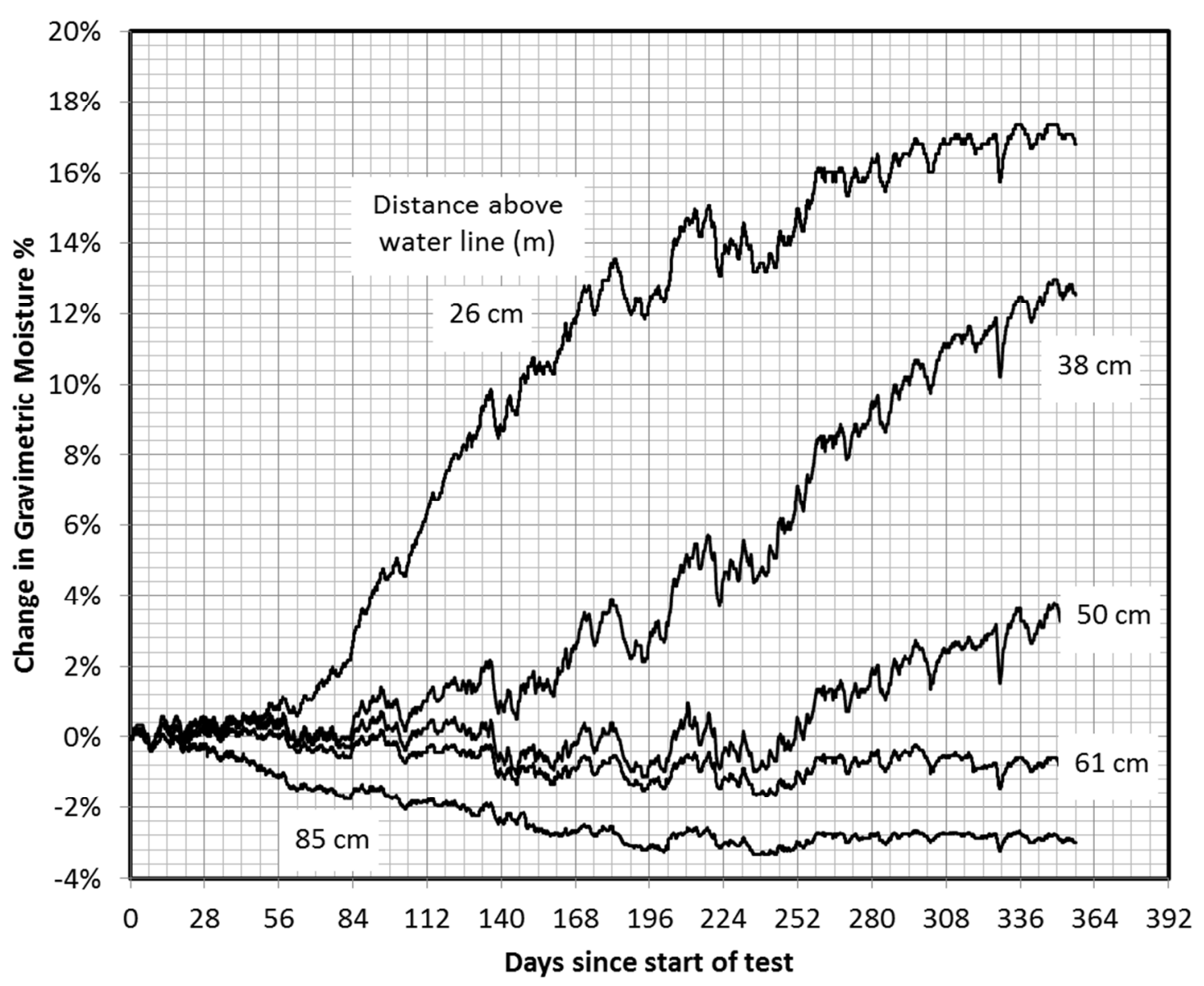

Figure 8. Moisture content versus time during capillary rise for the treated soil specimen. 


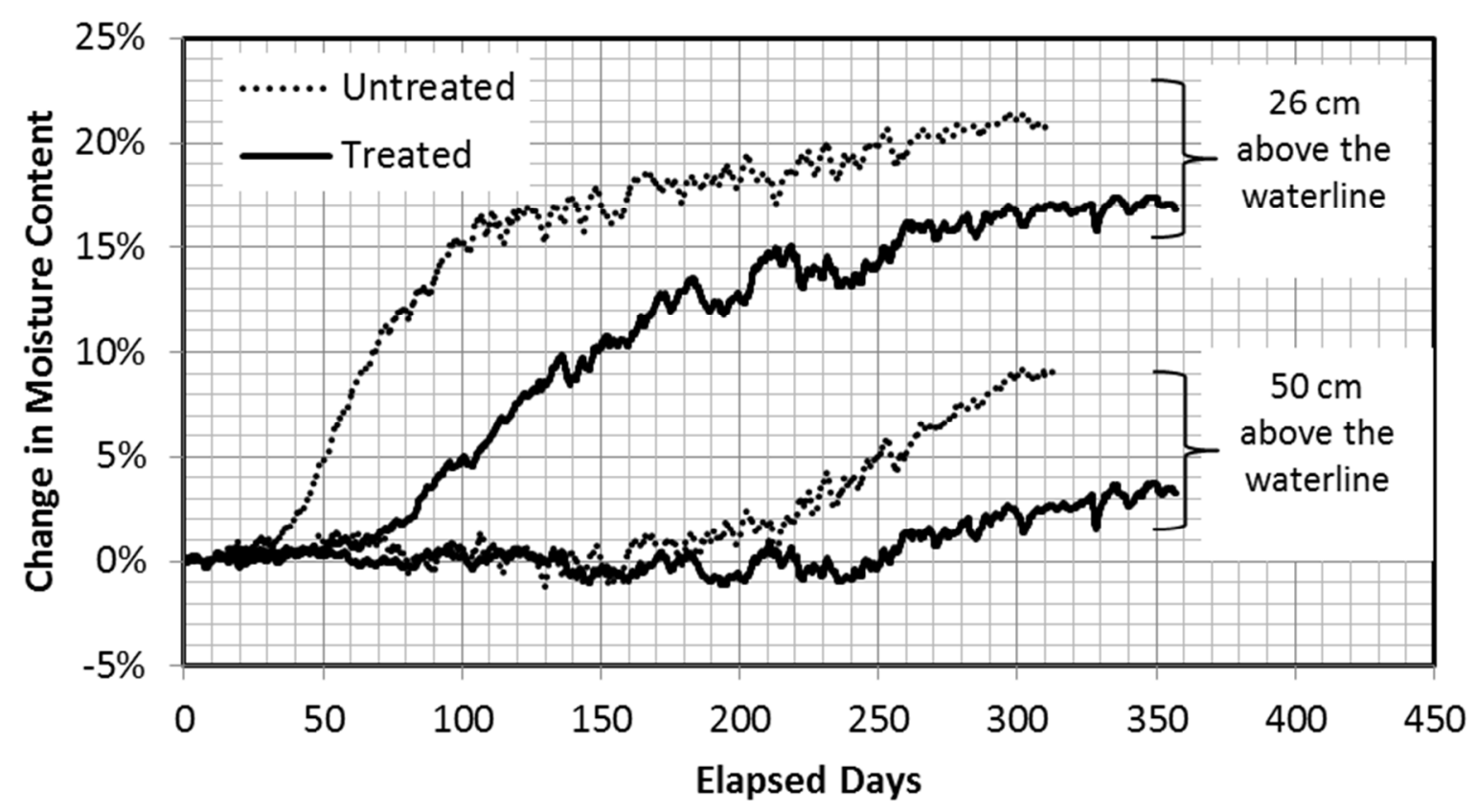

Figure 9. Comparison of moisture content versus time for treated and untreated soil. 
(a)

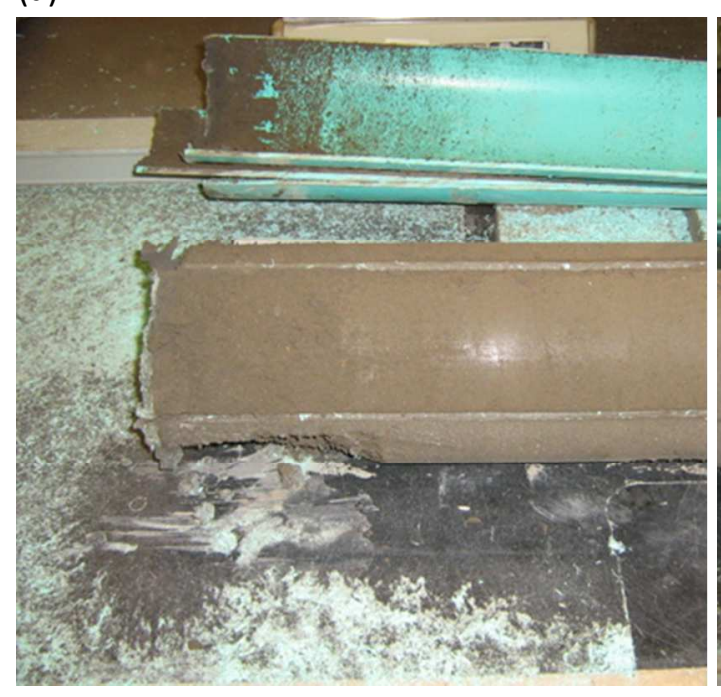

(b)

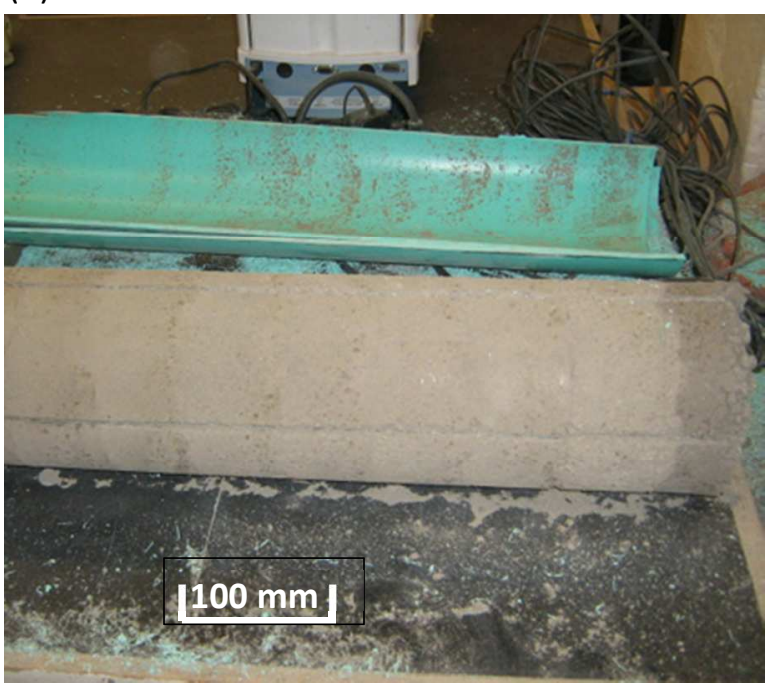

Figure 10. Photographs of the soil column at the end of the test. (a) Lower, wetter soil shown on the left and (b) higher, dryer soil shown on the right. 


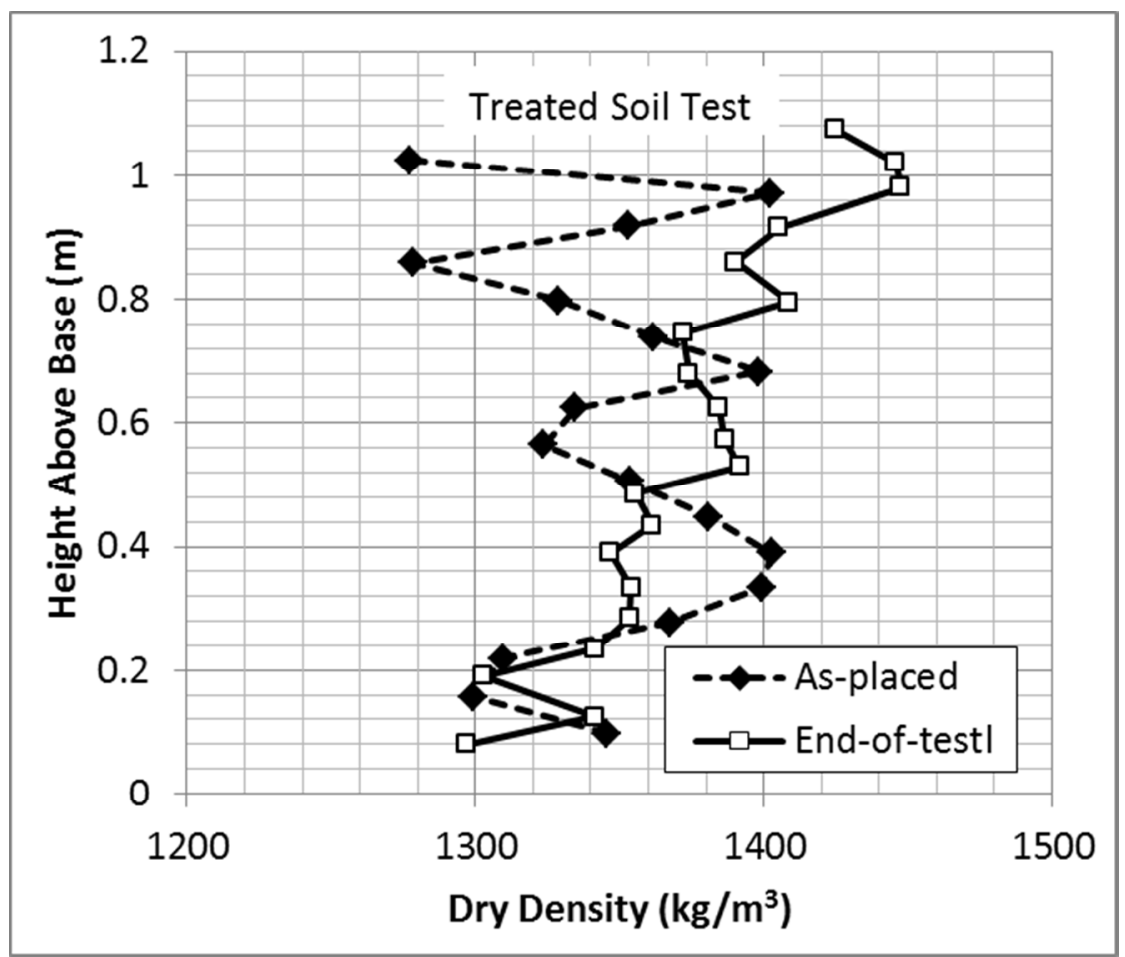

Figure 11. As-placed and end-of-test dry density for the treated soil test. 


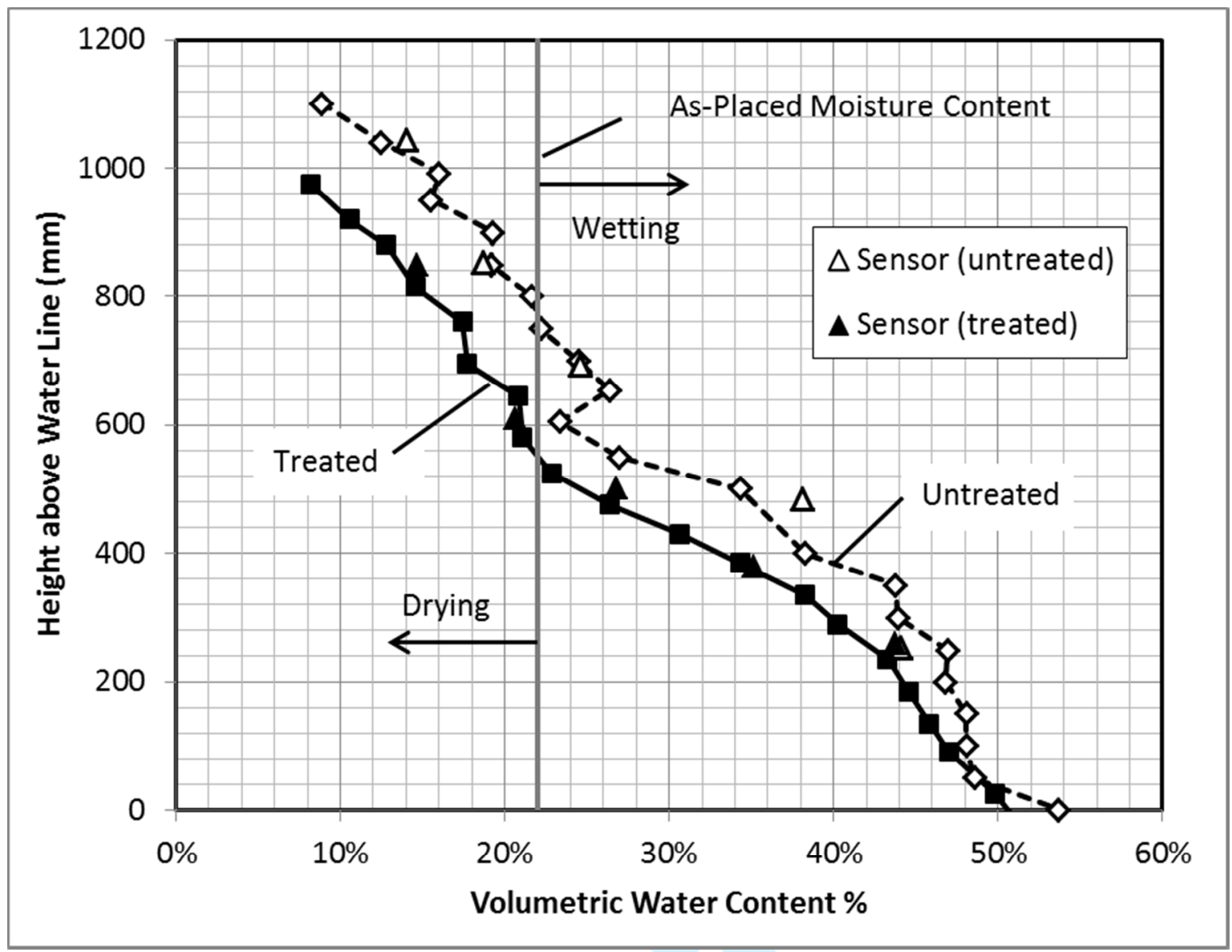

Figure 12. Comparison of end-of-test volumetric water content as a function of distance above the waterline. 